\title{
Hubungan Pembiayaan Bagi Hasil Terhadap Profitabilitas Perbankan Syariah di Indonesia
}

\author{
Priyono Puji Prasetyo \\ Fakultas Agama Islam, Program Studi Perbankan Syariah, Universitas Ahmad Dahlan, Yogyakarta, Indonesia \\ Email: priyono.prasetyo@pbs.uad.ac.id \\ Submitted: 16/11/2021; Accepted: 26/11/2021; Published: 30/11/2021
}

\begin{abstract}
Abstrak-Bank syariah memiliki fungsi memberikan layanan pembiayaan kepada para debitur diantaranya jenis pembiayaan bagi hasil dan jual beli. Pembiayaan ini diduga akan mempunyai pengaruh terhadap tingkat profitabilitas bank syariah. Karenanya, tujuan penelitian ini untuk menginvestigasi hubungan pembiayaan bagi hasil dan jual terhadap profitabilitas bank syariah di Indonesia. Populasi penelitian ini meliputi seluruh bank syariah. Sedangkan sampel penelitian menggunakan desain purposive sampling deng an pilihan Bank Umum Syariah (BUS) yang berjumlah 14 unit. Pembiayaan bagi hasil diwakili produk mudharabah dan musyarakah, sedangkan jual beli diwakili produk murabahah, salam dan istishna. Data yang digunakan dalam penelitian ini adalah laporan keuangan agregat BUS periode 2015-2019 dengan alat uji analisis data panel. Hasil temuan penelitian menunjukkan bahwa pembiayaan murabahah dan istishna' mempengaruhi probabilitas ROE. Sedangkan pembiayaan mudharabah dan musyarakah secara parsial mempengaruhi probabilitas ROA. Hasil uji simultan pembiayaan berbasis debt dan equity berpengaruh terhadap profitabilitas ROE. Rekomendasi pada penelitian berikutnya agar menambah jumlah tahun observasi penelitian untuk mendapatkan gambaran yang lebih komprehensif.
\end{abstract}

Kata Kunci: Bank Syariah; Bagi Hasil; Jual Beli; Pembiayaan; Profitabilitas

\begin{abstract}
Islamic banks have the function of providing financing services to debtors, including types of profit sharing and buying and selling financing. This financing is expected to influence the level of profitability of Islamic banks. Therefore, this study aims to investigate the relationship between profit sharing and selling financing on the profitability of Islamic banks in Indonesia. The population of this study includes all Islamic banks. At the same time, the research sample uses a purposive sampling design with a choice of 14 Islamic Commercial Banks (BUS). Profit-sharing financing is represented by mudharabah and musyarakah products, while buying and selling is represented by murabahah, salam, and istishna products. The data used in this study is the aggregated financial statements of BUS for the 2015-2019 period with panel data analysis test tools. The research findings show that murabahah and istishna' financing affect the probability of ROE. Meanwhile, mudharabah and musyarakah financing partially affect the probability of ROA. The simultaneous test of debt and equity-based financing affect ROE profitability. Recommendations in the subsequent research to increase the number of years of research observations to get a more comprehensive picture.
\end{abstract}

Keywords: Islamic Bank; Profit Sharing; Sale and Buy; Financing; Profitability

\section{PENDAHULUAN}

Bank syariah adalah bank yang menjalankan kegiatan usahanya berdasarkan Prinsip Syariah dan menurut jenisnya terdiri atas Bank Umum Syariah dan Bank Pembiayaan Rakyat Syariah(RI 2008). Kegiatan usaha bank syariah mencakup menghimpun dana dari masyarakat dengan fasilitas layanan produk tabungan, giro, dan deposito. Selanjutnya, kegiatan menyalurkan dana yang telah terhimpun kepada pihak-pihak yang membutuhkan dana baik untuk tujuan konsumtif, produktif dan lainnya. Selain itu, kegiatan jasa bank seperti layanan ATM, M-Banking, dan lainnya (Nafik, Ryandono, and Wahyudi 2018). Pertumbuhan aset, PYD dan DPK bank syariah mengalami peningkatan dari tahun ke tahun sebagaimana data statistik gambar 1:

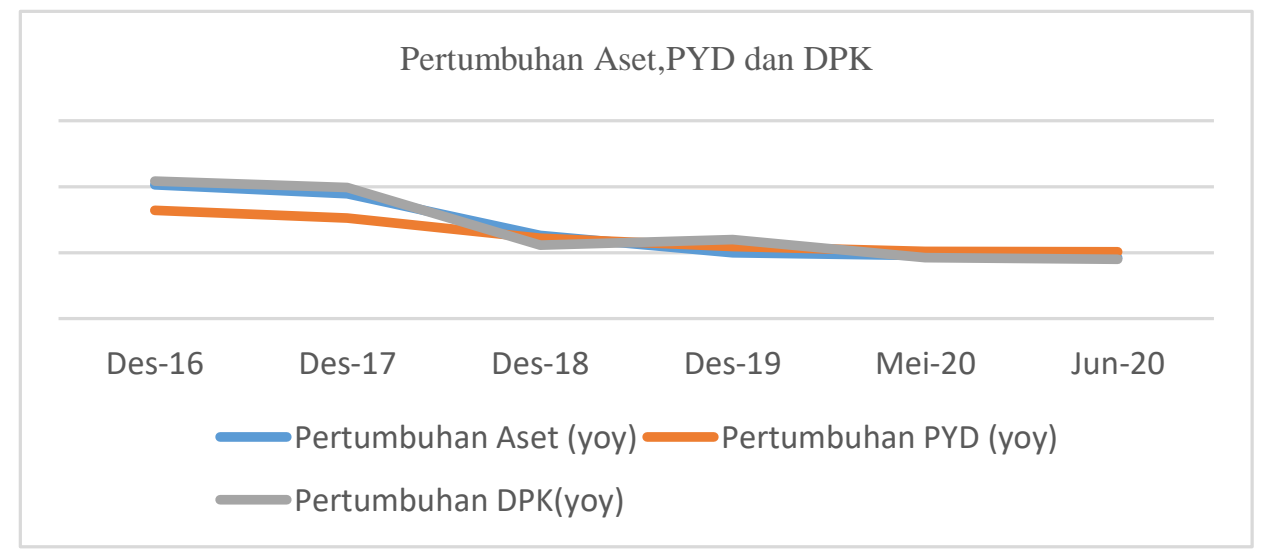

Gambar 1. Pertumbuhan Aset

Sumber: OJK (2020)

Sebagai lembaga bisnis, kegiatan usaha bank syariah mendapatkan keuntungan dari penyaluran dana(Santoso dan Ulfah Rahmawati 2016). Diantara jenis pembiayaan yang memberikan keuntungan produk bagi hasil, jual beli atau akad 
lain yang tidak bertentangan dengan prinsip syariah. Dengan penyaluran dana tersebut bank syariah akan mendapatkan keuntungan berupa bagi hasil dan marjin karena pembiayaan sebagai usaha utamanya(Yudha 2018).

Keuntungan dari pembiayaan mudharabah dan musyarakah berupa bagi hasil. Jadi, ketika bank syariah mendapatkan keuntungan maka akan dibagihasilkan dengan nasabah. Sebaliknya, jika bank mengalami kerugian dalam penyaluran pembiayaan maka pihak nasabah dan bank pun akan mengalami kerugian. Dengan kata lain, keuntungan dan kerugian dalam skema ini belum bisa diprediksi, bergantung dinamika bisnis nasabah. Sedangkan keuntungan jual beli telah bisa diprediksi karena telah ditetapkan diawal kontrak perjanjian (Nafik, Ryandono, and Wahyudi 2018) dan (Kuswara, Puji Lestari, and Retnaningsih 2019).

Profitabilitas ialah pengukuran kemampuan bank dalam memperoleh laba. Bagi pihak stakeholder, profitabilitas bank syariah menjadi salah satu ukuran dalam memutuskan menjadi nasabahnya. Bagi bank syariah sendiri, profitabilitas menjadi indikator utama kinerja dalam memperoleh keuntungan. Pada umumnya, tingkat pembiayaan memiliki hubungan positif terhadap profitabilitas bank syariah. Beberapa studi menunjukkan hubungan tersebut, misalnya penelitian Rahayu et al (Rahayu, Husaini, and Azizah 2016) periode 2011-2016, Sari dan Anshori (Sari and Anshori 2017) periode 20152016, Yulia et al (Inayatillah and Subardjo 2017) periode 2011- 2015, (Indah Wahyuningsih 2017) periode 2011-2015, Haris dan Yozika (Romdhoni and Yozika 2018) periode 2010-2016 dan Nawawi et al. (Nawawi, Nurdiansyah, and Al Qodliyah 2018) periode 2009-2016.

Studi tentang pembiayaan berbasis bagi hasil dengan produk mudharabah dan musyarakah terhadap profitabilitas bank syariah telah banyak dilakukan. Penelitian secara parsial telah dilakukan oleh Yentisna dan Alvian di BNI Syariah(Ermiwati 2019), Studi di BPR Syariah yang dilakukan Dharma dan Pristianda (Dharma 2018), studi pada Bank Umum Syariah oleh Inayah et al. (Nurul Inayah, Anik Malikah 2020).

Penelitian yang dilakukan oleh Haekal et al menguji dampak pembiayaan berbasis bagi hasil terhada ROA Bank Umum Syariah observasi tahun 2015-2018. Temuannya, memberikan kesimpulan bahwa baik pembiayaan berbasis bagi hasil memiliki pengaruh signifikan positif terhadap ROA (Zakaria, Manda, and Rakhman 2020). Studi yang dilakukan oleh Sari yang menganalisis pembiayaan mudharabah, musyarakah dan murabahah terhadap profitabilitas pada Bank Umum Syariah 2007-2014. Temuannya, menunjukkan bahwa pembiayaan bank syariah memiliki pengaruh terhadap Profitabilitas (Mulia Sari 2015).

Studi Rohmah dan Komariah (Rokhmah 2017) melakukan studi untuk menguji pembiayaan bagi hasil terhadap profitabilitas periode 2011-2015. Temuannya, mengejutkan bahwa pembiayaan mudharabah berpengaruh signifikan terhadap profitabilitas sedangkan pembiayaan musyarakah tidak memiliki pengaruh terhadap profitabilitas. Demikian halnya dengan temuan Teri dan Novitasari, yang menunjukkan bahwa pembiayan bank syariah mempunyai pengaruh terhadap ROA(Teri;Novitasari 2020).

Studi Wahyuningsih menganalisis pembiayaan mudharabah di Bank Muamalat Indonesia menunjukkan temuan bahwa terdapat pengaruh variabel dependen terhadap independen (Indah Wahyuningsih 2017). Arsyadona et al. juga melakukan studi dengan menguji dampak pembiayaan berbasis bagi hasil terhadap ROA. Dan hasilnya menunjukkan bahwa pembiayaan mudharabah dan musyarakah berpengaruh signifikan terhadap profitabilitas bank syariah (Arsyadona et al. 2019).

Berdasarkan literatur review, banyak studi empiris telah dilakukan untuk menguji pembiayaan berbasis bagi hasil dengan produk mudharabah dan musyarakah terhadap profitabilitas bank syariah. Namun, hasil empiris yang telah ada, bagaimanapun, menghasilkan hasil yang beragam. Selain itu, indikator profitabilitas hanya menggunakan ROA. Berdasarkan uraian grand theory dan literatur review, maka hipotesis dan peta jalan penelitian ini adalah sebagai berikut.

$\mathrm{H}_{1}$ : Pembiayaan berbasis debt financing berpengaruh positif dan signifikan terhadap Profitabilitas ROE

$\mathrm{H}_{2}$ : Pembiayaan berbasis equity financing berpengaruh positif dan signifikan terhadap Profitabilitas ROA

Sebagian besar studi sebelumnya, pada faktanya studi yang dilakukan oleh para peneliti menggunakan periode lampau. Dengan kata lain, studi ini akan menampilkan perkembangan perbankan syariah di Indonesia dalam konteks kekinian dengan data terbaru. Selanjutnya, studi ini akan menampilkan rasio utama profitabilitas ROA dan ROE. Dimana kedua rasio tersebut menurut Tamimi [12] dan Javaid [13] rasio yang paling populer digunakan untuk mengukur profitabilitas industri keuangan. Selanjutnya, temuan penelitian sebelumnya masih menunjukkan hasil yang berbedabeda. Oleh sebab itu, penelitian ini penting untuk dilakukan untuk menginvestigasi data yang lebih terkini. Di sinilah urgensi dari penelitian ini sekaligus menjadi alasan mengapa penelitian ini penting dilakukan.

\section{METODE PENELITIAN}

\subsection{Kerangka Dasar Penelitian}

Penelitian ini menggunakan desain asosiatif untuk menguji pembiayaan berbasis bagi hasil terhadap ROA dan ROE. Seluruh Bank Umum Syariah (BUS) di Indonesia menjadi populasi dari penelitian ini yang berjumlah 14. Sampel penelitian menggunakan metode purposive sampling dengan kriteria diantaranya; Bank Umum Syariah yang mendapatkan izin operasional OJK, mempunyai laporan keuangan tahunan periode 2010-2019. Sehingga sampel yang sesuai dengan kriteria berjumlah 3 (tiga) Bank Umum Syariah. Analisis data menggunakan regresi data panel karena data yang digunakan merupakan gabungan antara cross section dan time serries dengan regresi linier berganda sebagai metode analisis data. 


\section{HASIL DAN PEMBAHASAN}

Terlihat bahwa proporsi pembiayaan berbasis debt financing dan equity financing berubah-ubah setiap tahunnya. Tabel 1 menjelaskan besaran pembiayaan yang disalurkan oleh bank syariah setiap tahunnya.

Tabel 1. Besaran Pembiayaan

\begin{tabular}{|c|c|c|c|c|c|c|}
\hline \multirow{2}{*}{ Tahun } & \multicolumn{6}{|c|}{ Variabel } \\
\hline & ROE & ROA & Mudharabah & Musyarakah & Murabahah & Istishna' \\
\hline 2010 & 9.57 & 0.82 & Rp 623.716.147.936 & Rp 2.441.256.411.016 & Rp 3.619.641.191.057 & Rp 29.374.286.696 \\
\hline 2011 & 9.39 & 0.75 & $\operatorname{Rp} 771.912 .818 .216$ & Rp 3.237.471.111.579 & Rp 5.532.983.498.333 & Rp 34.156.528.466 \\
\hline 2012 & 14.76 & 0.99 & Rp 1.013.035.058.783 & Rp 5.067.874.134.740 & Rp 8.296.980.922.992 & Rp 14.113.324.135 \\
\hline 2013 & 9.75 & 0.78 & Rp 1.128.855.625.667 & $\operatorname{Rp} 7.525 .103 .864 .333$ & Rp 10.197.318.371.667 & Rp 15.663.583.667 \\
\hline 2014 & 1.65 & 0.17 & Rp 956.524.879.333 & Rp 8.249.053.345.000 & Rp 10.901.598.398.333 & Rp 12.373.608.667 \\
\hline 2015 & 4.82 & 0.59 & Rp 853.733.278.511 & Rp 8.930.387.538.975 & Rp 10.078.732.670.332 & Rp 8.529.308.994 \\
\hline 2016 & 5.18 & 0.64 & Rp 802.051.402.027 & Rp 9.149.386.890.493 & Rp 9.861.241.765.917 & Rp 6.002.249.187 \\
\hline 2017 & 1.72 & 0.21 & Rp 572.439.392.759 & Rp 9.035.467.052.128 & Rp 10.476.183.527.718 & Rp 4.146.901.175 \\
\hline 2018 & 1.22 & 0.17 & Rp 337.133.063.406 & Rp 8.738.322.215.250 & Rp 9.386.460.571.689 & Rp 3.379.197.331 \\
\hline 2019 & 0.67 & 0.12 & Rp 414.610.080.037 & Rp 9.388.487.762.817 & Rp 9.496.141.152.665 & $\mathrm{Rp} 2.687 .018 .868$ \\
\hline
\end{tabular}

Pembagian porsi pembiayaan pada bank syariah setiap tahunnya berubah, hal ini dapat dipengaruhi oleh banyak faktor, seperti kolektibiliti pembiayaan, bagi hasil, hingga jumlah DPK (Adzimatinur, Hartoyo, and Wiliasih 2013). Hal ini mempengaruhi rasio keuangan yang menjadi salah satu pedoman debitur untuk menyimpan dananya di bank syariah. Sebelum menguji secara statistik data yang diperoleh, dilakukan uji asumsi klasik.

1. Uji Normalitas

Uji normalitas digunakan untuk melihat apakah sebaran data terdistribusi normal atau tidak.

Tabel 2. Hasil Uji Normalitas

\begin{tabular}{|c|c|c|c|}
\hline & One-S & $\begin{array}{l}\text { Imogorov-Smirnov Test } \\
\text { Unstandardized } \\
\text { Residual_ROE }\end{array}$ & $\begin{array}{l}\text { Unstandardized } \\
\text { Residual_ROA }\end{array}$ \\
\hline $\mathrm{N}$ & & 10 & 10 \\
\hline \multirow[t]{3}{*}{ Normal Parameters ${ }^{\mathrm{a}, \mathrm{b}}$} & Mean & .0000000 & .0000000 \\
\hline & Std. & 365.02900040 & 17.26858148 \\
\hline & Deviation & & \\
\hline Most Extreme & Absolute & .191 & .220 \\
\hline \multirow[t]{2}{*}{ Differences } & Positive & .191 & .110 \\
\hline & Negative & -.194 & -.220 \\
\hline Test Statistic & & .191 & .220 \\
\hline Asymp. Sig. (2-tailed) & & .200 & .185 \\
\hline
\end{tabular}

Sumber: data diolah, 2021

Nilai signifikasi pada uji normalitas apabila menunjukkan angka lebih dari 0.05 maka data tersebut terdistribusi normal. Hasil uji normalitas pada tabel 2 yang dilakukan pada variable murabahah dan istishna' terhadap ROE memperoleh nilai signifikasi sebesar 0.200 atau lebih besar dari 0.05 dapat disimpulkan bahwa data terdistribusi normal. Pengujian terhadap variable mudharabah dan musyarakah pada ROA memperoleh hasil 0.185 (nilai sig >0.05) yang membuktikan bahwa data terdistribusi normal.

2. Uji Multikolinearitas

Uji multikolinearitas diperlukan untuk menganalisis ada tidaknya variable independen yang mempunyai kemiripan dengan variable independent dalam satu model regresi. Jika hasil uji multikolinearitas menunjukkan nilai tolerance lebih besar dari 0.10 dan nilai VIF lebih kecil dari 10.00 artinya tidak terjadi multikolinieritas.

Tabel 3. Hasil Uji Multikolinearitas H1

\begin{tabular}{|c|c|c|c|c|c|c|c|}
\hline \multirow[b]{2}{*}{ Model } & \multicolumn{2}{|c|}{$\begin{array}{c}\text { Unstandardized } \\
\text { Coefficients }\end{array}$} & \multirow{2}{*}{$\begin{array}{c}\text { Standardized } \\
\text { Coefficients } \\
\text { Beta } \\
\end{array}$} & \multirow[b]{2}{*}{$\mathrm{t}$} & \multirow[b]{2}{*}{ Sig. } & \multicolumn{2}{|c|}{ Collinearity Statistics } \\
\hline & $\mathrm{B}$ & Std. Error & & & & Tolerance & VIF \\
\hline $1 \quad$ (Constant) & 180.221 & 1179.248 & & .153 & .883 & & \\
\hline murabahah & $3.459 \mathrm{E}-12$ & .000 & .017 & .033 & .974 & .312 & 3.203 \\
\hline istishna & $2.888 \mathrm{E}-8$ & .000 & .659 & 1.276 & .243 & .312 & 3.203 \\
\hline
\end{tabular}

a. Dependent Variable: ROE 
Tabel 4. Hasil Uji Multikolinearitas H2

\begin{tabular}{|c|c|c|c|c|c|c|c|}
\hline \multirow[b]{2}{*}{ Model } & \multicolumn{2}{|c|}{$\begin{array}{l}\text { Unstandardized } \\
\text { Coefficients }\end{array}$} & \multirow{2}{*}{$\begin{array}{c}\text { Standardized } \\
\text { Coefficients } \\
\text { Beta } \\
\end{array}$} & \multirow[b]{2}{*}{$\mathrm{t}$} & \multirow[b]{2}{*}{ Sig. } & \multicolumn{2}{|c|}{ Collinearity Statistics } \\
\hline & $\mathrm{B}$ & Std. Error & & & & Tolerance & VIF \\
\hline (Constant) & 57.875 & 29.507 & & 1.961 & .091 & & \\
\hline Mudharabah & $6.361 \mathrm{E}-11$ & .000 & .505 & 2.472 & .043 & .966 & 1.035 \\
\hline Musyarakah & $-7.388 \mathrm{E}-12$ & .000 & -.593 & -2.906 & .023 & .966 & 1.035 \\
\hline a. Dependent Var & ROA & & & & & & \\
\hline
\end{tabular}

Sumber: data diolah, 2021

Pada tabel 4 merupakan hasil uji multikolinearitas pada variable ROE, murabahah, istishna memperoleh nilai tolerance sebesar 0.312 dan nilai VIF 3.203 sehingga dapat disimpulkan bahwa tidak terjadi multikolinearitas. Pada pengujian variable ROA, musyarakah, dan mudharabah dengan nilai tolerance 0.966 dan nilai VIF sebesar 1.035 yang membuktikan tidak terjadi multikolinieritas.

3. Uji Autokorelasi

Uji autorkorelasi run test dilakukan dalam penelitian ini untuk menguji apakah residual terdapat korelasi yang tinggi, jika tidak terdapat korelasi maka dikatakan bahwa nilai residual adalah acak atau random.

Tabel 5. Hasil Uji Autokorelasi

\begin{tabular}{lrr}
\hline & $\begin{array}{c}\text { Runs Test } \\
\text { Unstandardized } \\
\text { Residual_ROE }\end{array}$ & $\begin{array}{c}\text { Unstandardized } \\
\text { Residual_ROA }\end{array}$ \\
\hline Test Value $^{\mathrm{a}}$ & -124.17458 & 2.36167 \\
Cases < Test Value & 5 & 5 \\
Cases > Test Value & 5 & 5 \\
Total Cases & 10 & 10 \\
Number of Runs & 6 & 6 \\
Z & .000 & .000 \\
Asymp. Sig. (2-tailed) & 1.000 & 1.000 \\
\hline a. Median & & \\
\hline
\end{tabular}

Sumber: data diolah, 2021

Hasil uji terdapat gejala autokorelasi apabila nilai Asymp.Sig.(2-tailed) lebih kecil dari 0,05 dan tidak terdapat gejala autokorelasi apabila nilai Asymp.Sig. (2-tailed) lebih besar daripada 0,05. Dari hasil uji diperoleh hasil bahwa variabel murabahah, istishna dan ROE sebesar 1,000 menandakan bahwa tidak terdapat gejala autokorelasi antar variabel. Nilai yang sama juga diperoleh atas uji variabel mudharabah, musyarakah terhadap ROA yaitu sebesar 1,000 yang juga menandakan bahwa tidak terdapat gejala autokorelasi.

4. Uji Heteroskedasitas

Uji heteroskedasitas dilakukan untuk menguji apakah terjadi ketidaksamaan antara varian residual satu dengan lainnya. Hal ini dilihat melalui grafik scatterplot, tidak terdapat pola tertentu yang teratur maka diidentifikasi tidak terdapat heterokedastistas pada model regresi ini.
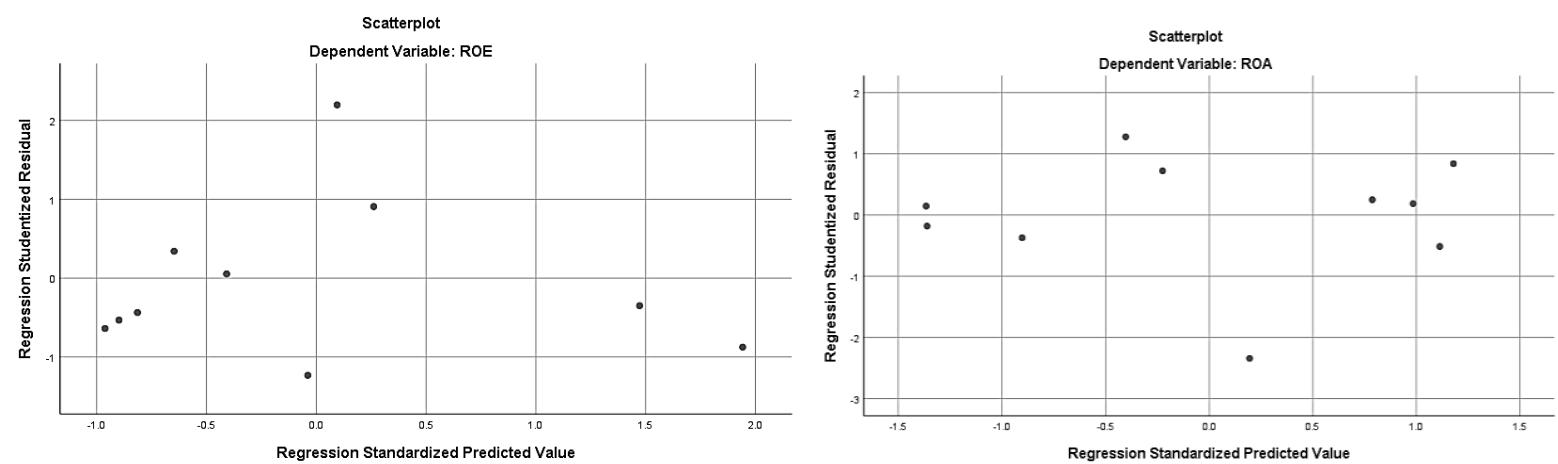

Gambar 2. Hasil Uji Heteroskedasitas

Sumber: data diolah, 2021

\subsection{Analisis Regresi Linear Berganda}

Teknik regresi linear berganda digunakan karena variabel dependen yang diuji dipengaruhi oleh dua variabel independent. 1. Uji Parsial (Uji t) 
Hasil uji parsial digunakan untuk melihat pengaruh Sebagian dari masing-masing variabel independent terhadap variabel dependen. Pengaruh pembiayaan berbasis debt financing terhadap probabilitas ROE

Tabel 6. Hasil Uji Parsial H1

\begin{tabular}{|c|c|c|c|c|c|}
\hline \multicolumn{6}{|c|}{ Coefficients $^{\mathrm{a}}$} \\
\hline \multirow[t]{2}{*}{ Model } & \multicolumn{2}{|c|}{ Unstandardized Coefficients } & $\begin{array}{c}\text { Standardized } \\
\text { Coefficients }\end{array}$ & \multirow[b]{2}{*}{$\mathrm{t}$} & \multirow[b]{2}{*}{ Sig. } \\
\hline & $\mathrm{B}$ & Std. Error & Beta & & \\
\hline (Constant) & 180.221 & 1179.248 & & .153 & .883 \\
\hline Murabahah & $3.459 \mathrm{E}-12$ & .000 & .017 & .033 & .047 \\
\hline Istishna' & $2.888 \mathrm{E}-8$ & .000 & .659 & 1.276 & .014 \\
\hline a. Dependent Var & & & & & \\
\hline
\end{tabular}

Sumber: data diolah, 2021

Tabel 6 menunjukkan hasil nilai signifikasi 0.047 pada variabel murabahah dan 0.024 pada variabel istishna' kurang dari 0.05 (nilai sig. < 0.05) sehingga dapat diartikan bahwa pembiayaan murabahah dan istishna' mempengaruhi probabilitas ROE.

Tabel 7. Hasil Uji Parsial H2

\begin{tabular}{|c|c|c|c|c|c|c|}
\hline \multicolumn{7}{|c|}{ Coefficients $^{\mathrm{a}}$} \\
\hline \multirow{2}{*}{\multicolumn{2}{|c|}{ Model }} & \multicolumn{2}{|c|}{ Unstandardized Coefficients } & $\begin{array}{l}\text { Standardized } \\
\text { Coefficients }\end{array}$ & \multirow[b]{2}{*}{$\mathrm{t}$} & \multirow[b]{2}{*}{ Sig. } \\
\hline & & $\mathrm{B}$ & Std. Error & Beta & & \\
\hline \multirow[t]{3}{*}{1} & (Constant) & 57.875 & 29.507 & & 1.961 & .091 \\
\hline & Mudharabah & $6.361 \mathrm{E}-11$ & .000 & .505 & 2.472 & .043 \\
\hline & Musyarakah & $-7.388 \mathrm{E}-12$ & .000 & -.593 & -2.906 & .023 \\
\hline & ependent Vari & & & & & \\
\hline
\end{tabular}

Sumber: data diolah, 2021

Tabel 7 menunjukkan hasil nilai signifikasi 0.043 pada variabel mudharabah dan 0.023 pada variabel musyarakah kurang dari 0.05 (nilai sig. < 0.05) sehingga dapat diartikan bahwa pembiayaan mudharabah dan musyarakah secara parsial mempengaruhi probabilitas ROA.

2. Uji Koefisiensi Determinasi (Uji $\left.\mathrm{R}^{2}\right)$

Hasil uji koefisiensi determinasi digunakan untuk melihat seberapa besar pengaruh variabel independent terhadap variabel dependen.

Tabel 8. Hasil Uji R ${ }^{2} \mathrm{H} 1$

\begin{tabular}{llrrr}
\hline Model & $\mathrm{R}$ & R Square & $\begin{array}{r}\text { Model Summary } \\
\text { Adjusted R Square }\end{array}$ & Std. Error of the Estimate \\
\hline 1 & $.645^{\mathrm{b}}$ & .416 & .249 & 413.90398 \\
\hline $\begin{array}{l}\text { a. predictors: (constant), murabahah, istishna' } \\
\text { b. dependent variable: roe }\end{array}$
\end{tabular}

Sumber: data diolah, 2021

Hasil uji koefisiensi determinasi pada pembiayaan berbasis debt financing menunjukkan hasil 0.249 , angka tersebut memberikan kesimpulan bahwa variabel ROE 24.9\% dipengaruhi oleh murabahah dan istishna'. Dan $75.1 \%$ dipengaruhi oleh variabel lain yang tidak di uji pada penelitian ini.

Tabel 9. Hasil Uji R ${ }^{2} \mathrm{H} 2$

\begin{tabular}{|c|c|c|c|c|}
\hline \multicolumn{5}{|c|}{ Model Summary ${ }^{\mathrm{b}}$} \\
\hline Model & $\mathrm{R}$ & R Square & Adjusted R Square & Std. Error of the Estimate \\
\hline 1 & $.847^{\mathrm{a}}$ & .718 & .637 & 19.58073 \\
\hline $\begin{array}{l}\text { a. predic } \\
\text { b. depen }\end{array}$ & $\begin{array}{l}\text { (cons } \\
\text { varia }\end{array}$ & $\begin{array}{l}\text { t), mudhara } \\
\text { roe }\end{array}$ & syarakah & \\
\hline
\end{tabular}
Sumber: data diolah, 2021

Hasil uji koefisiensi determinasi pada pembiayaan berbasis equity financing menunjukkan hasil 0.637 angka tersebut memberikan kesimpulan bahwa variabel ROA 63.7\% dipengaruhi oleh mudharabah dan musyarakah. Dan $36.3 \%$ dipengaruhi oleh variabel lain yang tidak di uji pada penelitian ini.

3. Uji Simultan (Uji F)

Hasil uji simultan digunakan untuk melihat bagaimana pengaruh variabel independent terhadap variabel dependen secara keseluruhan. 
Tabel 10. Hasil Uji Simultan H1

\begin{tabular}{llrrrrr}
\hline \multirow{2}{*}{ Model } & & \multicolumn{3}{c}{ ANOVA $^{\mathbf{a}}$} & & \multicolumn{2}{c}{ Sig. } \\
\hline 1 & Regression & 855172.560 & 2 & 427586.280 & 9.496 & $.015^{\text {b }}$ \\
& Residual & 1199215.540 & 7 & 171316.506 & & \\
& Total & 2054388.100 & 9 & & & \\
\hline
\end{tabular}

a. Dependent Variable: roe

b. Predictors: (Constant), istishna, murabahah

Sumber: data diolah, 2021

Berdasarkan hasil pengujian dapat dilihat bahwa hasil uji $\mathrm{F}$ menunjukkan nilai nilai sig yang diperoleh adalah $0.015<0.05$ sehingga dapat disimpulkan bahwa secara simultan pembiayaan berbasis debt equity berpengaruh terhadap profitabilitas ROE.

Tabel 11. Hasil Uji Simultan $\mathrm{H} 2$

\begin{tabular}{|c|c|c|c|c|c|c|}
\hline \multicolumn{7}{|c|}{ ANOVA $^{a}$} \\
\hline Model & & Sum of Squares & df & Mean Square & $\mathrm{F}$ & Sig. \\
\hline \multirow[t]{3}{*}{1} & Regression & 6832.565 & 2 & 3416.282 & 8.910 & $.012^{\mathrm{b}}$ \\
\hline & Residual & 2683.835 & 7 & 383.405 & & \\
\hline & Total & 9516.400 & 9 & & & \\
\hline $\begin{array}{l}\text { a. Depe } \\
\text { b. Pred }\end{array}$ & $\begin{array}{l}\text { lent Variab } \\
\text { ors: (Const }\end{array}$ & $\begin{array}{l}\text { a } \\
\text { musyarakah, muc }\end{array}$ & bah & & & \\
\hline
\end{tabular}

Sumber: data diolah, 2021

Berdasarkan hasil pengujian dapat dilihat bahwa hasil uji $\mathrm{F}$ menunjukkan nilai nilai sig yang diperoleh adalah $0.012<0.05$ sehingga dapat disimpulkan bahwa secara simultan pembiayaan berbasis equity berpengaruh terhadap profitabilitas ROA

\section{KESIMPULAN}

Hasil temuan penelitian menunjukkan bahwa pembiayaan murabahah dan istishna' mempengaruhi probabilitas ROE. Sedangkan pembiayaan mudharabah dan musyarakah secara parsial mempengaruhi probabilitas ROA. Hasil uji simultan pembiayaan berbasis debt dan equity berpengaruh terhadap profitabilitas ROE. Rekomendasi pada penelitian berikutnya agar menambah jumlah tahun observasi penelitian untuk mendapatkan gambaran yang lebih komprehensif.

\section{UCAPAN TERIMAKASIH}

Terima kasih disampaikan kepada LPPM Universitas Ahmad Dahlan yang telah memberikan pendanaan penelitian dengan nomor kontrak Nomor: PD-371/SP3/LPPM-UAD/V/2021.

\section{REFERENCES}

Adzimatinur, Fauziyah, Sri Hartoyo, and Ranti Wiliasih. 2013. 'Faktor-Faktor Yang Memengaruhi Besaran Pembiayaan Perbankan Syariah Di Indonesia Factors Affecting The Amaunt of Financing Islamic Banking in Indonesia 2 Tinjauan Pustaka'. Jurnal AlMuzara'ah: 106-21.

Al-tamimi, Hussein A Hassan. 2010. 'Factors Influencing Performance of the UAE Islamic and Conventional National Banks'. Global Journal Of Business Research 4(2): 1-9.

Arsyadona, Saparuddin Siregar, Isnaini Harahap, and M Ridwan. 2019. 'The Effects Of Mudharabah And Musyarakah Financing On The Profitability Of Sharia Commercial Banks In Indonesia'. Proceeding International Seminar on Islamic Studies 1(1): 68289.

Dharma, Yulius dan Ade Pristianda. 2018. 'Pengaruh Pembiayaan Mudharabah Dan Murabahah Terhadap Profitabilitas (Return On Assets) Bank Pembiayaan Rakyat Syariah Di Indonesia 2012-2016’. Jurnal Ekonomika Indonesia VII(2): 60-64.

Ermiwati. 2019. 'Pengaruh Pembiayaan Mudharabah Dan Musyarakah Terhadap Tingkat Profitabilitas Pada Bank Bni Syariah Tahun 2015 - 2017’. Menara Ilmu XIII(2): 102-14. http://jurnal.umsb.ac.id/index.php/menarailmu/article/view/1189.

Inayatillah, Yulia, and Anang Subardjo. 2017. 'Pengaruh Pembiayaan Bagi Hasil , Pembiayaan Jual Beli, FDR, NPF Terhadap Profitabilitas Bank Syariah'. Jurnal Ilmu dan Riset Akuntansi 6(12): 1-17.

Indah Wahyuningsih. 2017. 'Pengaruh Pendapatan Pembiayaan Mudharabah Terhadap Profitabilitas (ROA) Pada PT. Bank Muamalat Indonesia Tbk. Periode 2011-2015'. Tasharruf: Journal Economic and Business Of Islam 2(2): 185-211.

Javaid, Saima, and Suha Alalawi. 2018. 'Performance and Profitability of Islamic Banks in Saudi Arabia: An Empirical Analysis'. Asian Economic and Financial Review 8(1): 38-51.

Kuswara, Dimas Puja, Etty Puji Lestari, and Tri Kurniawati Retnaningsih. 2019. 'Determinant of Islamic Banking Profitability In Indonesia'. Jurnal Organisasi dan Manajemen 15(1): 36-45.

Mulia Sari. 2015. 'Pengaruh Pembiayaan Mudharabah, Pembiayaan Musyarakah, Dan Pembiayaan Murabahah Terhadap Profitabilitas Pada Bank Syariah Manidiri Dan Bank Muamalat Indonesia (Studi Pada Bank Umum Syariah Yang Terdaftar Di Bank Indonesia 
Periode Triwulan I 2007- Triwulan'. JURNAL AKUNIDAAKUNIDA 2(1): 43-58.

Nafik, Muhamad, Hadi Ryandono, and Rofiul Wahyudi. 2018. Manajemen Bank Islam: Pendekatan Syariah Dan Praktik. Yogyakarta: UAD Press.

Nawawi, Ahmad, Dian Hakip Nurdiansyah, and Diffah Sri Addafi Al Qodliyah. 2018. 'Pengaruh Pembiayaan Mudharabah Dan Musyarakah Terhadap Profitabilitas (ROA) Pada BPRS HIK Bekasi Kantor Cabang Karawang'. FALAH: Jurnal Ekonomi Syariah 3(2): 96.

Nurul Inayah, Anik Malikah, Abdul Wahid Mahsuni. 2020. 'Pengaruh Tabungan Wadi'ah, Giro Wadi'ah, Bonus Wadi'ah, Pembiayaan Mudharabah, Dan Pembiayaan Musyarakah Terhadap Laba Bank Umum Syari’ah Periode 2014-2019'. E-Jra 09(02): 47-57.

Rahayu, Y., A. Husaini, and D. Azizah. 2016. 'Pengaruh Pembiayaan Bagi Hasil Mudharabah Dan Musyarakah Terhadap Profitabilitas (Studi Pada Bank Umum Syariah Yang Terdaftar Pada Bursa Efek Indonesia Periode 2011-2014)'. Jurnal Administrasi Bisnis (JAB) 33(1): 61-68.

RI. 2008. 151 Undang-Undang Republik Indonesia tentang perbankan syariah.

Rokhmah, Laila; dan Euis Komariah. 2017. 'Pengaruh Pembiayaan Bagi Hasil Mudharabah Dan Musyarakah Terhadap Profitabilitas Pada Bank Umum Syariah Di Indonesia.' Jurnal Ilmiah MBiA Vol.16 16(1): 11-20.

Romdhoni, Abdul Haris, and Ferlangga El Yozika. 2018. 'Pengaruh Pembiayaan Mudharabah, Musyarakah Dan Ijarah Terhadap Profitabilitas Bank Muamalat Indonesia'. Jurnal Ilmiah Ekonomi Islam 4(03): 177.

Santoso dan Ulfah Rahmawati. 2016. 'Produk Kegiatan Usaha Perbankan Syari'ah Dalam Mengembangkan Umkm Di Era Mas yarakat Ekonomi Asean (MEA) Santoso Dan Ulfah Rahmawati Universitas Islam Sultan Agung Semarang Abstrak A . Pendahuluan Bank Syari ’ Ah Memiliki Kewajiban Untuk Memastikan Kea'. Jurnal Penelitian 10(2): 322-43.

Sari, Dewi Wulan, and Mohamad Yusak Anshori. 2017. 'Pengaruh Pembiayaan Murabahah, Istishna, Mudharabah, Dan Musyarakah Terhadap Profitabilitas (Studi Pada Bank Syariah Di Indonesia Periode Maret 2015 - AGUSTUS 2016)'. Accounting and Management Journal 1(1): 1-8.

Teri;Novitasari, Dyan. 2020. 'Pengaruh Pendapatan Pembiayaan Murabahah, Mudharabah, Dan Musyarakah Terhadap Profitabilitas Pada Bank Syariah Yang Terdaftar Di Bursa Efek Indonesia. Accounting, Accountability and Organization System Journal (AAOS) 1(2): 188-200. https://journal.unifa.ac.id/index.php/aaos.

Yudha, Ana Toni Roby Candra dan Akmalur Rijal. 2018. 'Pembiayaan Bagi Hasil, Pembiayaan Jual Beli Dan Risiko Pembiayaan Serta Margin Laba Pada Bank Syariah'. In Manajemen, Akuntansi Dan Perbankkan 2018, , 1289-1309. http://conferences.uinmalang.ac.id/index.php/semnasfe/article/view/770.

Zakaria, Heikal Muhammad, Gusganda Suria Manda, and Arif Rakhman. 2020. 'Analisis Penggunaan Pembiayaan Mudharabah Dan Pembiayaan Musyarakah Terhadap Profitabilitas Di Bank Umum Syariah Periode 2015-2018’. Eqien: Jurnal Ekonomi dan Bisnis 7(2): 71-76. 